\title{
Various Freezing Strategies of Flower-bud Hardiness in Prunus
}

\author{
Sorkel A. Kadir ${ }^{1}$ \\ Mount Vernon Research and Extension Unit, 1468 Memorial Highway, Mount Vernon, WA 98273-9788 \\ Edward L. Proebsting ${ }^{2}$ \\ Irrigated Agriculture Research and Extension Center, Prosser, WA 99350-9687
}

\begin{abstract}
Additional index words. chill unit, differential thermal analysis, supercooling, Prunus salicina, Prunus domestica, Prunus hortulana, Prunus nigra, Prunus americana, Prunus armeniaca, Prunus dulcis, Prunus triloba, Prunus davidiana, Prunus persica, Prunus japonica, Prunus tomentosa, Prunus besseyi, Prunus subhirtella, Prunus avium, Prunus fruticosa, Prunus emarginata, Prunus padus, Prunus serotina, Prunus virginiana
\end{abstract}

\begin{abstract}
Flower buds of 20 Prunus species showed quite different strategies to cope with low temperatures. Buds of most species deep supercooled. The two hardiest species, both from the subgenus Padus (P. padus L. and P. virginiana L.), did not supercool and survived $-33 \mathrm{C}$ with no bud kill. Prunus serotina J.F. Ehrh., also in Padus, did supercool. Prunus nigra Ait., P. americana Marsh, $P$. fruticosa Pall., and $P$. besseyi L.H. Bailey had a low minimum hardiness level (MHL), small buds, and a low water content. Exotherms were no longer detectable from the buds of these species after 2 days at -7C and some buds survived -33C. Prunus triloba Lindl. and $P$. japonica Thunb. were similar to that group, but no buds survived -33C. Prunus davidiana (Carriere) Franch., $P$. avium L., and $P$. domestica L. had a relatively high MHL but hardened rapidly when the buds were frozen. Prunus persica (L.) Batsch., P. subhirtella Miq., P. dulcis (Mill) D. A. Webb, and $P$. emarginata (Dougl. ex Hook) Walp. deep supercooled, had large flower buds and a high MHL, and were killed in the Dec. 1990 freeze. Prunus salicina Lindl., P. hortulana L.H. Bailey, P. armeniaca L., and $P$. tomentosa Thunb. were in an intermediate group with a moderately low MHL and a moderate rate of hardiness increase while frozen. Prunus dulcis and $P$. davidiana had a low chilling requirement and bloomed early, whereas $P$. virginiana, $P$. fruticosa, $P$. nigra, and $P$. domestica had high chilling requirements and bloomed late.
\end{abstract}

Prunus species, native and introduced, are widely distributed in North America. Reputed hardiness ranges from zone 7 (P. umbellata Ell.) to zone 2 (P. virginiana) (Rehder, 1951). Within the genus are several adaptations that help flower buds survive low temperatures. Most Prunus species supercool to avoid freezing injury. Others, such as $P$. padus and $P$. virginiana, do not supercool and, thus, resist freezing. The hardier, nonsupercooling species bear flowers on racemose inflorescences that can survive $-80 \mathrm{C}$ (Rajashekar and Burke, 1978). Flower buds that supercool can increase their hardiness quickly by rapidly moving water out of the florets to extraorgan ice crystallization sites while the tissues are frozen (Ishikawa and Sakai, 1982; Quamme, 1978). This process results in maximum hardiness after extended periods in the frozen state. The rate at which bud hardiness increases is species dependent (Proebsting and Mills, 1972). All species have a characteristic level of hardiness that is maintained while the buds are not frozen. This property, which is also species dependent (Proebsting and Mills, 1972), has been called the minimum hardiness level (MHL) (Proebsting, 1963). The MHL decreases during fall acclimation and rises during deacclimation in late winter and early spring.

Prunus species are classified (Rehder, 1951) into five subgenera. Two of the subgenera are further subdivided into three or seven sets. Flower buds of 20 species of Prunus were chosen to represent all taxonomic groups available in the Irrigated Agriculture Re-

Received for publication 7 June 1993. Accepted for publication 5 Oct. 1993. H/LA paper no. 93-14, College of Agriculture and Home Economics Research Center, Washington State Univ., Pullman. Supported in part by a grant from the Washington Tree Fruit Research Commission. We thank William Howell and Gaylord Mink for plant material from the NRSP-5 repository (formerly IR-2). The cost of publishing this paper was defrayed in part by the payment of page charges. Under postal regulations, this paper therefore must be hereby marked advertisement solely to indicate this fact.

${ }^{1}$ To whom reprints requests should be addressed.

${ }^{2}$ Horticulturist. search and Extension Center (IAREC), Prosser, Wash., orchards. The objective of this study was to identify the freezing characteristics of the selected Prunus species to be used in future studies to improve bud hardiness of commercial Prunus cultivars.

\section{Materials and Methods}

Plant material. Twenty Prunus species, representing native and introduced material, were selected for this study. Four of the five subgenera and all of the sets except for Lobopetalum, Phyllomahalb, and Phyllocerasus in the subgenus Cerasus (Table 1) were represented. Shoots from each species were collected at 2-week intervals during Winters 1989-90 and 1990-91 from the IAREC orchards, including those of the National Research Support Project (NRSP-5; formerly Interregional Project 2). Shoots were placed in polyethylene bags and covered with ice for transport from the orchard to the laboratory. Samples were prepared immediately.

Unequal numbers of determinations were unavoidable. Several Prunus species were killed by the freezing temperature that hit the area during Dec. 1990. Limited supplemental data, such as fresh weight of the flower buds, were collected in 1993. Data were analyzed by the general linear models procedure.

Winter 1989-90 was mild. Samples were collected on schedule throughout the winter. In 1990-91, there was a month of continuous subfreezing temperatures from 11 Dec. to 11 Jan., broken only by a 9C day on 27 Dec. On 29 Dec., the minimum was -21.7C. During that period, almost all flower buds of $P$. persica, $P$. dulcis, $P$. subhirtella, and $P$. emarginata were killed and, thus, were not used for further testing.

Differential thermal analysis. Samples of 15 to 20 flower buds were detached from the shoots, collected as mentioned in the previous section along with 1 to $2 \mathrm{~mm}$ of bark tissue, and placed on both sides of a thermoelectric module with 71 thermocouple junctions sandwiched between two conductive plates (Andrews et 
Table 1. Classification, hardiness zone, and primordia per bud of Prunus species selected for this study (Rehder, 1951).

\begin{tabular}{|c|c|c|c|}
\hline Classification & & $\begin{array}{l}\text { Hardiness } \\
\text { zone }\end{array}$ & $\begin{array}{c}\text { Primordium/ } \\
\text { bud }\end{array}$ \\
\hline Subgenus I. & PRUNOPHORA & & \\
\hline Set 1 . & Euprunus & & \\
\hline \multirow[t]{2}{*}{ Species } & P. salicina Lindl. & 3 & $2-3$ \\
\hline & P. domestica L. & 4 & 1 \\
\hline Set 2 . & Prunocerasus & & \\
\hline \multirow[t]{3}{*}{ Species } & P. hortulana L.H. Bailey & 5 & 1 \\
\hline & P. nigra Ait. & 2 & 1 \\
\hline & P. americana Marsh. & 3 & 1 \\
\hline Set 3 . & Armeniaca & & \\
\hline Species & P. armeniaca $\mathrm{L}$. & 5 & 1 \\
\hline Subgenus II. & AMYGDALUS & & \\
\hline \multirow[t]{4}{*}{ Species } & P. dulcis (Mill) D.A. Webb. & 6 & 1 \\
\hline & P. davidiana (Carriere) Fra. & 5 & 1 \\
\hline & P. triloba Lindl. & 5 & 1 \\
\hline & P. persica (L.) Batsch. & 4 & 1 \\
\hline Subgenus III. & CERASUS & & \\
\hline Set 1 . & Microcerasus & & \\
\hline \multirow[t]{3}{*}{ Species } & P. besseyi L.H. Bailey & 3 & $3-5$ \\
\hline & P. japonica Thunb. & 2 & $2-3$ \\
\hline & P. tomentosa Thunb. & 2 & $1-2$ \\
\hline Set 2 . & Pseudocerasus & & \\
\hline Species & P. subhirtella Miq. & 5 & $2-5$ \\
\hline Set 4 . & Eucerasus & & \\
\hline \multirow[t]{2}{*}{ Species } & P. avium L. & 3 & $2-6$ \\
\hline & P. fruticosa Pall. & 3 & $2-4$ \\
\hline Set 5 . & Mahaleb & & \\
\hline Species & P. emarainata (Dougl. ex Hook) Walp. & 6 & $3-10$ \\
\hline Subgenus IV. & PADUS & & \\
\hline \multirow[t]{3}{*}{ Species } & P. padus L. & 3 & Numerous \\
\hline & P. serotina J. F.Ehrh. & 3 & Numerous \\
\hline & P. virginiana $\mathrm{L}$. & 2 & Numerous \\
\hline
\end{tabular}

al., 1983). The buds were held in place with aluminum foil. One sample of flower buds on the prepared plates was subjected to artificial hardening at $-7 \mathrm{C}$ in a freezer and another to dehardening in a cold room at $3 \mathrm{C}$ for 2 to 3 days. Plates held at $-7 \mathrm{C}$ were transferred to the freezer in thermos bottles to prevent thawing the samples.

Storing buds at $-7 \mathrm{C}$ tested the rate of increase in hardiness while frozen (Proebsting and Mills, 1972), whereas storage at 3C represented the MHL (Proebsting, 1963). After preconditioning, the plates were suspended in a double-walled styrofoam box in a programmable freezer. The $3 \mathrm{C}$ samples were placed in the box at $0 \mathrm{C}$ and the $-7 \mathrm{C}$ samples were placed in the box when the box temperature reached $-7 \mathrm{C}$. The samples were cooled to $-33 \mathrm{C}$ at $4 \mathrm{C} / \mathrm{h}$.

Freezing of the flower-bud primordia was recorded as exothermic events on a multiple-channel strip-chart potentiometer (Linseis L7060; Princeton Junction, N.J.). The temperature in the box was measured with a 36-gauge copper-constantan thermocouple. When the temperature of the freezer reached $-33 \mathrm{C}$, samples were removed, held for $24 \mathrm{~h}$ at $23 \mathrm{C}$ and $100 \%$ relative humidity, and then observed for the presence of tissue oxidation.

Hardiness components. Hardiness was measured on samples collected in December and January. The median low-temperature exotherm $\left(\mathrm{LTE}_{50}\right)$, the rate of increase in hardiness $\left(\Delta \mathrm{LTE}_{50}\right)$, and the percentage of flower buds that survived $-33 \mathrm{C}$ were determined. The percentage of flower primordium that supercooled was expressed as the ratio of the number of LTEs to the total number of flower primordia within the sample (LTEs per primordium).

Chilling requirement. Beginning in December, $15-$ to $20-\mathrm{cm}-$ long twigs were collected weekly from each species for forcing at room temperature (23C). Rest was considered ended when $>50 \%$ of the buds reached the first swelling stage within 3 days. Chill unit accumulation (CUA) was calculated using the Utah model (Richardson et al., 1974).

The date of first microspore meiosis was observed in anthers fixed with 1 to 2 drops of $1 \mathrm{~g}$ acetocarmine in $45 \%$ acetic acid for 10 to 15 min.

Dye uptake. The cut ends of twigs were placed into $1 \%$ azosulfamide and held at room temperature for 2 days (Ashworth and Rowse, 1982). The location of the dye was observed in longitudinal sections of the flower bud.

Water content. During 1990-91, water content was determined by drying the buds at $90 \mathrm{C}$ for $24 \mathrm{~h}$ and was expressed as the percentage of fresh weight.

\section{Results and Discussion}

Deep supercooling. The occurrence of supercooling as detected with thermopiles varied between and within species. Some species never appeared to supercool and some species produced LTEs at the MHL but not after 2 days at $-7 \mathrm{C}$ (Table 2). Some species varied in their ability to produce detectable LTEs. No species yielded $100 \%$ LTEs. All species lost the ability to deep supercool as the buds developed after endodormancy. 
Table 2. Percentage of LTEs per primordium, average $\mathrm{LTE}_{50}$ during dormant season after 2 days at $3 \mathrm{C}$ minimum hardiness level (MHL), change in $\mathrm{LTE}_{50}$ after 2 days at $-7 \mathrm{C}$, percentage of living buds at $-33 \mathrm{C}$ after 2 days at 3 or $-7 \mathrm{C}$, fresh weight (mg/bud), and percentage of water content $\left(\mathrm{mg} \cdot \mathrm{mg}^{-1}\right.$ fresh weight) of dormant Prunus flower buds. ${ }^{\mathrm{z}}$

\begin{tabular}{|c|c|c|c|c|c|c|c|c|c|}
\hline \multirow[b]{2}{*}{ Subgenus } & \multirow[b]{2}{*}{ Set } & \multirow[b]{2}{*}{ Species } & \multirow{2}{*}{$\begin{array}{c}\text { LTEs/ } \\
\text { primordium } \\
(\%)\end{array}$} & \multirow{2}{*}{$\begin{array}{l}\text { MHL } \\
\left({ }^{\circ} \mathrm{C}\right)\end{array}$} & \multirow[b]{2}{*}{$\Delta \mathrm{LTE}_{50}$} & \multicolumn{2}{|c|}{$\begin{array}{c}\text { Alive bud } \\
(\%)\end{array}$} & \multirow{2}{*}{$\begin{array}{l}\mathrm{FW}^{\mathrm{y}} \\
(\mathrm{mg})\end{array}$} & \multirow{2}{*}{$\begin{array}{l}\mathrm{WC}^{\mathrm{x}} \\
(\%)\end{array}$} \\
\hline & & & & & & 3 & -7 & & \\
\hline \multirow[t]{6}{*}{ Prunophora } & 1 & P. salicina & 65 & -22 & 2 & 0 & 19 & 3 & 40 \\
\hline & & P. domestica & 67 & -22 & 6 & 0 & 0 & 7 & 38 \\
\hline & 2 & P. hortulana & 57 & -22 & Absent & 0 & 0 & 4 & 46 \\
\hline & & P. nigra & 57 & -27 & Absent & 0 & 93 & 7 & 28 \\
\hline & & P. americana & 65 & -27 & Absent & 0 & 90 & 6 & 30 \\
\hline & 3 & P. armeniaca & 81 & -22 & 4 & 0 & 0 & 11 & 40 \\
\hline \multirow[t]{4}{*}{ Amygdalus } & & P. triloba & 57 & -24 & 3 & 0 & 0 & 3 & 40 \\
\hline & & P. davidiana & 81 & -17 & 7 & 0 & 0 & 14 & 65 \\
\hline & & P. persica & 78 & -18 & 1 & 0 & 0 & 13 & $--{ }^{w}$ \\
\hline & & P. dulcis & 77 & -19 & Absent & 0 & 0 & 16 & --- \\
\hline \multirow[t]{7}{*}{ Cerasus } & 1 & P. japonica & 65 & -23 & Absent & 0 & 0 & --- & 32 \\
\hline & & P. tomentosa & 80 & -25 & 3 & 0 & 0 & 3 & 54 \\
\hline & & P. besseyi & 39 & -25 & Absent & 94 & 100 & 3 & 25 \\
\hline & 2 & P. subhirtella & 65 & -20 & 4 & 0 & 0 & 12 & --- \\
\hline & 4 & P. avium & 77 & -21 & 6 & 0 & 0 & 31 & 51 \\
\hline & & P. fruticosa & 68 & -24 & Absent & 0 & 45 & 4 & 28 \\
\hline & 5 & P. emarginata & 15 & -20 & 5 & 0 & 0 & 15 & --- \\
\hline \multirow[t]{3}{*}{ Padus } & & P. padus & Absent & Absent & Absent & 100 & 100 & 28 & --- \\
\hline & & $P$. serotina & 50 & -23 & Absent & 0 & 0 & 10 & --- \\
\hline & & P. virginiana & Absent & Absent & Absent & 100 & 100 & 26 & --- \\
\hline $\operatorname{LSD}_{(P=0.05)}$ & & & & 2 & & & 14 & & \\
\hline
\end{tabular}

${ }^{\mathrm{Z}}$ Values are average of at least four observations during 1989-90 and 1990-91.

${ }^{\mathrm{y}}$ Calculated from 1993 data.

xValues measured during 1990-91 only.

${ }^{\text {w}}$ Killed by $1990-91$ freeze.

As previously reported (Rajashekar and Burke, 1978), P. padus and P. virginiana in the subgenus Padus did not deep supercool and were very hardy. In our study, all buds survived $-33 \mathrm{C}$ whether they were preconditioned at -7 or at 3 C. Prunus serotina, also in the subgenus Padus, supercooled to an average of $-23 \mathrm{C}$ (Kader and Proebsting, 1992), an exception to the generalization that inflorescences of Padus species do not supercool (Ashworth, 1982; Rajashekar and Burke, 1978). All three of these species have racemose inflorescences.

There were six other species, $P$. nigra, $P$. americana, $P$. hortulana, $P$. japonica, $P$. besseyi, and $P$. fruticosa, that did not show LTEs after 2 days at $-7 \mathrm{C}$. Buds of these species, except for $P$. hortulana and $P$. japonica, had in common that they 1 ) were small, 2) had low water content, 3) had a low minimum hardiness level, 4) usually lost their exotherms after $-7 \mathrm{C}$ exposure, and 5) survived $-33 \mathrm{C}$ after exposure to $-7 \mathrm{C}$ (Table 2). Probably these four species showed no detectable LTEs because, being small with low water content, there was insufficient water to generate enough heat to be detected by our system. The disappearance of LTEs from buds held at subfreezing temperatures has been observed previously in $P$. besseyi and $P$. pensylvanica (Burke and Stushnoff, 1979; Quamme et al., 1982).

Prunus hortulana had somewhat larger flower buds and higher water content but still lost enough water that LTEs were not detected after being held at $-7 \mathrm{C}$ for 2 days. Nevertheless, the flower buds did not survive exposure to -33 C. Prunus japonica was similar to the other four species in this group except that the flower buds did not survive-33C. $P$. japonica, as $P$. besseyi, did not always have detectable LTEs, even when not frozen. Unfrozen buds of $P$. americana, $P$. nigra, and $P$. hortulana did not show
LTEs in Dec. 1990 but did in Jan. 1991.

It has been known for a long time that ice forms in the bud scales and pith of peach flower buds (Dorsey, 1934). Quamme (1978) associated ice development at these sites with the ability of peach flower buds to deep supercool. In hardy conifers, there is a cavity in the crown that accommodates ice crystals, permitting deep supercooling (Sakai, 1979).

Under the dissecting microscope, living buds of $P$. nigra and $P$. americana had green primordia, crown, and axial pith and a brown region just beneath the crown area. It may be postulated that buds of $P$. nigra and $P$. americana developed a pith cavity, which served as the primary site for ice crystals rather than between the bud scales.

$M H L$. The average MHL ranged from $-17 \mathrm{C}$ for $P$. davidiana to $-28 \mathrm{C}$ for P. nigra (Table 2). Generally, Prunus species were hardier in 1990-91 than 1989-90 (data not shown), except for $P$. hortulana, $P$. tomentosa, $P$. avium, and $P$. serotina. There was no relationship between taxonomic classification and MHL. Each subgenus had examples of high and low MHLs, except for the subgenus Padus, in which there was no deep supercooling, excluding $P$. serotina.

The MHL related significantly to several attributes reported in this paper (Table 3 ). The hardiness zone assigned to the species by Rehder (1951) no doubt was intended to represent all manifestations of hardiness, not just flower buds. Nevertheless, there was a highly significant relationship between hardiness zone and MHL. Small buds and low water content were related to low MHL. The typical number of primordia per bud was not related to MHL. Early blooming species had a higher MHL and it related significantly to the date that meiosis was first observed and to bloom date. The 
chilling requirement was not related to MHL.

Rate of decrease in LTE ${ }_{50}$ while frozen. Very rapid changes in hardiness were observed in $P$. davidiana, the species with the highest MHL, and with $P$. avium and $P$. domestica, each having a relatively high MHL (Table 2) and reliable winter survival in the Yakima Valley. $\mathrm{LTE}_{50}$ in sweet cherries (P. avium) has been shown to decrease more rapidly in the first day at $-10 \mathrm{C}$ than on subsequent days (Andrews and Proebsting, 1987). Peach (P. persica) has a high MHL and slow rate of decrease in $\mathrm{LTE}_{50}$ at $-7 \mathrm{C}$ (Table 2). Peach and nectarine are the most prone to winter crop loss of the fruit species grown in the Yakima Valley. Prunus armeniaca crops are often lost to low temperature, but more often in the spring. During dormancy, $P$. armeniaca has a high to middle-range MHL and a relatively rapid rate of increase when frozen. Prunus avium

Table 3. Correlation coefficients among hardiness components of Prunus flower bud.

\begin{tabular}{lcc}
\hline \hline $\begin{array}{l}\text { Independent } \\
\text { component }\end{array}$ & $\begin{array}{c}\text { Dependent } \\
\text { component }\end{array}$ & $\begin{array}{c}\text { Correlation } \\
\text { coefficient }\end{array}$ \\
\hline Hardiness zone & MHL & $0.64^{* * *}$ \\
Water content & MHL & $0.71^{* *}$ \\
Bud weight & MHL & $0.57^{* *}$ \\
Date of meiosis & MHL & $0.51^{* *}$ \\
Date of bloom & MHL & $0.57^{* *}$ \\
No. of primordium/bud & MHL & $0.05^{\mathrm{NS}}$ \\
CUA & MHL & $0.40^{\mathrm{NS}}$ \\
CUA & Date of meiosis & $0.78^{* *}$ \\
CUA & Date of bloom & $0.80^{* *}$ \\
Date of meiosis & Date of bloom & $0.85^{* *}$ \\
No. of primordia/bud & Date of meiosis & $0.49^{*}$
\end{tabular}

${ }^{\bar{z}} \mathrm{MHL}=$ minimum hardiness level.

${ }^{\mathrm{y}}$ Chill unit accumulation to end rest.

${ }^{\mathrm{x}}$ Microspore meiosis.

Ns,*,**N Nonsignificant or significant at $P=0.05$ or 0.01 , respectively.

Table 4. Flower-bud development among Prunus species as represented by chill unit accumulation to end of rest, date, and stage of development at microspore meiosis and days to first bloom.

\begin{tabular}{|c|c|c|c|c|}
\hline \multirow{2}{*}{$\begin{array}{l}\text { Prunus } \\
\text { species }\end{array}$} & \multirow{2}{*}{$\begin{array}{c}\text { Chill unit } \\
\text { accumulation }\end{array}$} & \multicolumn{2}{|c|}{ Microspore meiosis } & \multirow{2}{*}{$\begin{array}{l}\text { Days to } \\
\text { bloom }\end{array}$} \\
\hline & & Date & Stage & \\
\hline P. salicina & 940 & 26 Feb. & Swelling & 88 \\
\hline P. domestica & 1336 & 12 Mar. & Swelling & 97 \\
\hline P. hortulana & 1025 & 5 Mar. & Side white & 93 \\
\hline P. nigra & 1336 & 12 Mar. & Swelling & 100 \\
\hline P. americana & 1185 & 12 Mar. & Side white & 94 \\
\hline P. armeniaca & 940 & 29 Jan. & Swelling & 69 \\
\hline P. triloba & 940 & 12 Mar. & First pink & 79 \\
\hline P. davidiana & 760 & 5 Jan. & Swelling & 58 \\
\hline P. persica & 1185 & 21 Feb. & Swelling & 89 \\
\hline P. dulcis & 740 & 22 Jan. & Swelling & 41 \\
\hline$P$. japonica & 840 & 8 Mar. & Tight cluster & 95 \\
\hline P. tomentosa & 840 & 8 Feb. & Swelling & 80 \\
\hline P. besseyi & 1070 & 7 Mar. & Side White & 100 \\
\hline P. subhirtella & 800 & 5 Feb. & Swelling & 69 \\
\hline P. avium & 1185 & 7 Mar. & Swelling & 96 \\
\hline P. fruticosa & 1336 & 19 Mar. & Green tip & 100 \\
\hline P. emarginata & 1200 & 29 Mar. & Green tip & --- \\
\hline P. padus & 1025 & 15 Mar. & Tight cluster & 94 \\
\hline P. virginiana & 1380 & 7 Apr. & Tight cluster & 105 \\
\hline$P$. serotina & 1285 & 22 Mar. & Green tip & 99 \\
\hline
\end{tabular}

and $P$. subhirtella behaved similarly to $P$. armeniaca.

The $P$. salicina used in this study was an anomaly, having a relatively high $\mathrm{MHL}$, a low rate of $\mathrm{LTE}_{50}$ decrease, and a relatively high water content, yet some of the buds survived exposure to 33C. Several commercial cultivars grow at Prosser in zone 5 or 6. The $P$. salicina used in this experiment was a reputedly hardy sample of the species in the NRSP-5 collection, not a commercial cultivar. Two commercial cultivars, Friar and Santa Rosa, had larger flower buds ( 3 vs. $1 \mathrm{mg}$ ), a similar MHL, and increased only $1 \mathrm{C}$ while frozen for 2 days. Their buds did not survive $-33 \mathrm{C}$.

Flower-bud development. Delayed bloom is a well recognized way to avoid low-temperature injury in the spring. That it is also related to MHL was noted above. A low chilling requirement among these species is quite well correlated with earlier bloom dates, assuming a linear relationship (Table 4). Prunus dulcis and $P$. davidiana completed their chilling in December and bloomed in February and early March. Species that required $>1300$ chilling hours, such as $P$. virginiana, $P$. nigra, $P$. domestica, $P$. fruticosa, and $P$. serotina, bloomed after 10 Apr.

The date of first meiosis was correlated with chilling requirement $\left(r^{2}=0.78\right)$, although not at a level useful for it's prediction (Table 3). The date of first meiosis showed a closer relationship to bloom date $\left(r^{2}=0.85\right)$, probably useful for a first estimate or as an early marker of bloom development (Proebsting, 1963). Multiple primordia in the bud were related to later date of meiosis.

During 1989-90, dye movement was used to observe the development of xylem vessels (XV) in Prunus flower buds throughout the season. In those species that supercooled during dormancy, dye did not enter the primordium, while dye was observed within the primordium of the subgenus Padus, as reported by Ashworth (1982). In 1990-91 as buds started to develop in late winter or early spring, we followed the development of XV in every part of the primordium to relate the presence or disappearance of LTEs to the development of XV. Generally, microscopic observations showed that, when the primordia lost the LTEs, XV were observed in the calyx.

Separating flower-bud hardiness into identifiable components may be valuable in future work to improve bud hardiness of commercial cultivars. The species selected for this study represented a fairly comprehensive cross section of the taxonomic groups in Prunus. They showed a variety of strategies for producing a crop after low winter temperatures, including low MHLs, rapid hardening when the buds are frozen, low moisture content, small buds, high chilling requirement, and late bloom. While these characteristics are interrelated, they also are expressed somewhat independently. For example, $P$. davidiana had the highest MHL, the second shortest chilling requirement, and the second earliest bloom date, yet produced a crop after the low temperature of Dec. 1990 because it hardened very rapidly while frozen.

\section{Literature Cited}

Andrews, P.K. and E.L. Proebsting. 1987. Effect of temperature on the deep supercooling characteristics of dormant and deacclimating sweet cherry flower buds. J. Amer. Soc. Hort. Sci. 112:334-340.

Andrews, P.K., E.L. Proebsting, and G.S. Campbell. 1983. An exotherm sensor for measuring the cold hardiness of deep-supercooled flower buds by differential thermal analysis. HortScience 18:77-78.

Ashworth, E.N. and D.J. Rowse. 1982. Vascular development in dormant Prunus flower buds and its relationship to supercooling. HortScience 17:790-791.

Burke, M.J. and C. Stushnoff. 1979. Frost hardiness: A discussion of the possible molecular causes of injury with particular reference to deep supercooling of water, p. 197-225. In: H. Mussell and R.C. Staples (eds.). Stress physiology in crop plants. Wiley, New York. 
Dorsey, M.J. 1934. Ice formation in the fruit bud of peach. Proc. Amer. Soc. for Hort. Sci. 31:22-27.

Ishikawa, M. and A. Sakai. 1982. Characteristics of freezing avoidance in comparison with freezing tolerance: A demonstration of extraorgan freezing, p. 325-340. In: P.H. Li and A. Sakai (eds.). Plant cold hardiness and freezing stress. vol 2. Academic Press, New York.

Kader, S.A. and E.L. Proebsting 1992. Freezing behavior of Prunus, subgenus Padus, flower buds. J. Amer. Soc. Hort. Sci. 117:955-960.

Proebsting, E.L. 1963. The role of air temperatures and bud development in determining hardiness of dormant Elberta peach fruit buds. Proc. Amer. Soc. Hort. Sci. 83:259-269.

Proebsting, E.L. and H.H. Mills. 1972. A comparison of hardiness responses in fruit buds of 'Bing' cherry and 'Elberta' peach. J. Amer. Soc. Hort. Sci. 97:802-806.

Quamme, H.A. 1978. Mechanism of supercooling in overwintering peach flower buds. J. Amer. Soc. Hort. Sci. 103:57-61.

Quamme, H.A., R.E.C. Layne, and W.G. Ronald. 1982. Relationship of supercooling to cold hardiness and the northern distribution of several cultivated and native Prunus species and hybrids. Can. J. Plant Sci. 62:137-148.

Rajashekar, C. and M.J. Burke. 1978. The occurrence of deep undercooling in the genera Pyrus, Prunus and Rosa: A preliminary report, p. 213225. In: P.H. Li and A. Sakai (eds.). Plant cold hardiness and freezing stress. Academic Press, New York.

Rehder, A. 1951. Manual of cultivated tress and shrubs. Macmillan, New York.

Richardson, E.A., S.D. Seeley, and D.R. Walker. 1974. A model for estimating the completion of rest for 'Redhaven' and 'Elberta' peach trees. HortScience 9:331-332.

Sakai, A. 1979. Freezing avoidance of primordial shoots of very hardy conifer buds. Low Temperature Sci. Ser. B 37:1-9. 